\title{
Enhanced Electric Machines and Power Course
}

\author{
Chih-Ping Yeh, Mulchand S. Rathod \\ Wayne State University
}

\begin{abstract}
This paper presents our experiences in developing a NSF-funded CCLI project for enhancing the 'Electric Machines and Power' course. The objective of this project is to provide a new structure to the existing course to enhance student learning of electric machines. The project involves (1) improving the long existing rotating machine laboratory by adding modern power electronic drives and devising real time data acquisition for measurement and analysis, (2) developing and implementing animation, simulation and visualization components to enhance student learning of electric machine, (3) configuring course to cover relevant theory while reducing topics to achieve effectiveness without credit hours or time change. This paper describes the planning steps and the development procedures of this project. The new course structure and laboratory experiments will be discussed.
\end{abstract}

\section{Introduction}

Though the traditional 'Energy conversion course' had remained almost unchanged for several decades, a redesigned structure has been proposed by several references over the last decade [1-2]. Types of motor drives worthy of addressing in undergraduate curricula are discussed [3]. Recently, LabView has been utilized in developing some animation for an EE course [4]. Multimedia projects founded by the NSF and the Department of Education suggest that visualization, animation and interactive simulation effectively help learners understand abstract concepts. However, there has been no major instances of a multimedia approach to EET electric machine courses.

In 1998, the Division of Engineering Technology (DET) at Wayne State University (WSU) had conducted a project to develop computer based instruction (CBI) materials for an Electric Machines course for the NSF-funded Greenfield Coalition (NSF-GC) for Manufacturing Education [5-8]. This course introduce industrial electric power source and industrial applications of motors, generators, and transformers to associate level manufacturing engineering and technology students. This project involved devising real time data acquisition using National Instruments (NI) LabView and data acquisition (DAQ) tools, and developing animation and simulation examples using Authorware/Flash and Pspice.

Presently, we utilized the results from the NSF-CG CBI development as background and extend the development to enhance an existing senior level 'Electric Machines and Power' course (EET 3500) in WSU's DET-EET program. The division has been awarded a NSF CCLI grant to carry 
out this work. In this paper, we describe the objective, planing steps and development procedures of this on-going project.

\section{Project Overview}

Due to the old technology and the traditional structure of the electric machine course, EET students in many institutions are not exposed to the advances in data acquisition, simulation, control and visualization that every modern industry currently employs for immediate date observation, analysis and presentation. It is difficult for students to apply their experience at work place. In order to prepare them for the challenges in industry, students must be taught using the latest technology embedded into advanced hardware and software tools. The purpose for building a new structure to the existing 'Electric Machines and Power' course (EET 3500) is to set a direction for providing hardware dominant experience in future technologists in microcontroller, DSP and embedded controllers that will compete for future motor drives and utility applications.

Another strong motivation for this project is that it significantly influences student selection of power electronics as a field of advanced study when electric power deregulation and fuel cell and battery driven electric/hybrid vehicles are becoming a reality within the near feature [1,2]. What can also be expected is an environment that helps students experience the latest advances in computer-aided simulation, analysis, and design of electromechanical system.

The objectives set for this project are:

- Configure the course to cover relevant theory while reducing topics that emphasized multiple characterization in the past, so that effectiveness is achieved without credit hours or time change.

- Improve the existing rotating machine laboratory by adding modern power electronic drives and devising real time data acquisition for measurement.

- Develop, enhance, adapt and implement animation, computer simulation and visualization to enhance student's learning.

- In the future, use enhanced courseware for delivery over the WWW or through distance.

\section{Enhanced Course Structure}

The content of the 'Electric Machines and Power' course (EET 3500) has been revised to retain major concepts while reducing topics to achieve effectiveness without credit hours or time change. This revision involves a structure attempt to include real time data acquisition, visualization and simulation components. Even with the inclusion of computer based components, seriously enhancing and maintaining hand-on experiences of the students are critical elements of the project.

Table I shows the comparison of the new course structure and the existing course, where all the changes are underlined. 
Table I. Existing EET 3500 course structure and new structure

\begin{tabular}{|c|c|}
\hline Existing EET 3500 Course Structure & Enhanced EET 3500 Course Structure \\
\hline $\begin{array}{l}\text { 1. Review of electric circuit, power and lab } \\
\text { safety }\end{array}$ & $\begin{array}{l}\text { I. Review of electric circuits, Power and lab safety } \\
\text { - Visualization: Power factor and its improvement }\end{array}$ \\
\hline $\begin{array}{l}\text { II. Magnetic circuits } \\
\text { - Analogy of electric and magnetic quantities } \\
\text { - Analysis of toroid and other core inductors }\end{array}$ & $\begin{array}{l}\text { II. Introduction to LabView, NIDAQ, Flux2D and } \\
\text { Magnetic circuits } \\
\text { - Analogy of electric and magnetic quantities } \\
\text { - Analysis of toroid and other core inductors } \\
\text { - Visualization of flux distribution in toroid } \\
\end{array}$ \\
\hline $\begin{array}{l}\text { III. Transformers } \\
\text { - Applications and transformer connections } \\
\text { - Ideal and non-ideal equivalent circuits } \\
\text { - Efficiency and losses } \\
\text { - Experiment on turns ratio, rating, efficiency } \\
\text { - Equivalent circuit parameter determination } \\
\text { - Special transformers }\end{array}$ & $\begin{array}{l}\text { III. Transformers } \\
\text { - Applications and transformer connections } \\
\text { - Ideal and non-ideal equivalent circuits } \\
\text { - Efficiency and losses } \\
\text { - Special transformers } \\
\text { - Experiment on turns ratio, rating, efficiency } \\
\text { - Visualization of flux distribution, Y- } \Lambda \text { voltage, currents } \\
\text { - } \underline{\text { Saber/Pspice simulation }}\end{array}$ \\
\hline $\begin{array}{l}\text { IV. DC Machine } \\
\text { - Application and topologies } \\
\text { - Performance-torque, efficiency and losses } \\
\text { - DC machine experience } \\
\text { - Measurement of resistance } \\
\text { - Open circuit and loaded characteristics } \\
\text { - Efficiency and losses }\end{array}$ & $\begin{array}{l}\text { IV. DC Machine } \\
\text { - Application and topologies } \\
\text { - Performance-torque, efficiency and losses } \\
\text { - DC machine experience: } \\
\text { - Visualization: Machine construction, Operating } \\
\text { principle, Interactive Flux2D based flux distribution } \\
\text { - Open circuit and loaded characteristics (Lab View) } \\
\text { - Efficiency and losses }\end{array}$ \\
\hline $\begin{array}{l}\text { V. Synchronous machines } \\
\text { - Application and types } \\
\text { - Rotating magnetic field, Equivalent circuits } \\
\text { - Efficiency and losses } \\
\text { - Synchronous machine experience: } \\
\text { - Open circuit and load characteristics } \\
\text { - Efficiency and losses }\end{array}$ & $\begin{array}{l}\text { V. Synchronous machines } \\
\text { - Application and types } \\
\text { - Rotating magnetic field, Equivalent circuits } \\
\text { - Efficiency and losses } \\
\text { - Synchronous machine experience: } \\
\text { - Visualization: Machine construction, Revolving field } \\
\text { - Open circuit and load characteristics (Lab View) } \\
\text { - Efficiency and losses }\end{array}$ \\
\hline $\begin{array}{l}\text { VI. Induction Machines } \\
\text { - Applications and types } \\
\text { - Effect of slop and equivalent circuit } \\
\text { - Performance - torque, efficiency and losses } \\
\text { - Induction motor experiments } \\
\text { - Direction of rotation } \\
\text {-Equivalent circuit parameter determination } \\
\text { - Speed torque characteristics } \\
\text { - Efficiency and losses } \\
\end{array}$ & $\begin{array}{l}\text { VI. Induction Machines } \\
\text { - Applications and types } \\
\text { - Effect of slop and equivalent circuit } \\
\text { - Performance - torque, efficiency and losses } \\
\text { - Induction motor experiments } \\
\text { - Direction of rotation } \\
\text { - Torque speed characteristics (Lab View) } \\
\text { - Efficiency and losses } \\
\text {-Visualization: Slip, number of poles, Flux distribution }\end{array}$ \\
\hline $\begin{array}{l}\text { VII. Power System } \\
\text { - Transmission line parameters } \\
\text { - Transmission line representation } \\
\text { - ABCD parameters } \\
\text { - Fault analysis } \\
\end{array}$ & $\begin{array}{l}\text { VII. Power System } \\
\text { - Transmission line parameters } \\
\text { - Transmission line representation } \\
\text { - ABCD parameters } \\
\text { - Fault analysis }\end{array}$ \\
\hline
\end{tabular}


The following interactive visualization and laboratory experiment are designed to be conducted after covering relevant theory in lecture.

Laboratory I: This experiment will begin with a tour of the laboratory. Student will be given safety guidelines. The essential features and the use of LabView, NIDAQ and Flux2D tools will be make known. Students will run the power factor and its improvement animations.

Laboratory II: Student will interactively visualize the flux and $\mathrm{mmf}$ distribution in inductors. Fringing flux due to air gap and flux distributions due to change in geometry/material/air gap length will be observed.

Laboratory III: Open circuit and load tests on single and three-phase transformer for understanding the connection, equivalent circuit, efficiency and losses are done. Animation examples demonstrate Wye-Delta voltage-current relationship.

Laboratory IV: Students derive open circuit saturation curve of a generator and devise motor speed control. Visualization examples enable observation of internal machine structure and also the flux distributions within. The interaction allows them observe effect due to changed number of poles. They acquire motor speed, torque and generated voltage signal for the DAQ board.

Laboratory V: Students study an alternator on load and load and the impact of load power factor on regulation and efficiency. They will observe voltage-current characteristics on computer screen. Visualization examples enable comparison between dc and synchronous machine structures.

Laboratory VI: In the visualization examples, students observe meaning of number of poles, revolving field, slip and slip speed. They also observe the flux distributions and compare with the dc machine fluxes. They examine the effect of phase sequence. Students will obtain torque-Speed characteristic on the LabView screen. They will calculate the efficiency of the IM.

The laboratory will also serve the 'Power Electronics' course (EET 4600) and 'Senior Project' course (EET 4999). In the future, the laboratory will enable experiments on power supplies, UPS and controllers. An additional experiment has been designed to support the study of power electronics and converter fed drives. Students will have the due theory on rectifiers, inverters and vector control in class. Knowing the controls of the dc SCR variable frequency, and the vector-controlled drive (AVCD), student will operate dc/ac drives in the laboratory. They will conduct closed loop and 4quardrant drive operation. They will also examine positioning, braking, regeneration, dynamometer performances via the AVCD drive.

\section{Planned Activities}

This project involves the development of the laboratory environment as a first stage. The second stage consists of developing two-dimensional finite element based interactive visualizations. The third stage involves the integration of DAQ tools with the dc/ac drives along with other components for the electric 
machines and power course. Projects that utilized LabView, NIDAQ, Authorware/Flash and Pspice as part of the NSF-CBI development and the resultant papers listed in the references [3-8] serve as background work for this work.

The complete process of the development compose of the following activities:

1) Installation of LabView, its Internet Developers kit (IDK) and the Fuzzy logic toolbox, Flux2D, Saber, Authorware/Flash.

2) Installation of NIDAQ board installation and setup of the four PC's to the division's network.

3) Careful study of the 4-quadrant dc and ac vector controller setup of the torque, speed, voltage and current feedback signal processing units.

4) Development of LabView front panel, configuration of DQ broads and generation of Authorware animations for loading on a central server.

5) Configuration of LabView IDK and creation of Flux2D visualization examples and Saber simulation examples.

6) Further tailoring of the CBI courseware from the already developed NSF-GC project to the EET 3500 course.

7) Evaluation and assessment of the new course structure by the recent graduates and Industrial Advisory Board of WSU DET.

To facilitate continuous improvement, the following means will be used for evaluating the project: End of semester student evaluation of the course will be obtained along with response to questions about the interactive components and the hand-on drive experiments. Feekback will be sought from graduated students about the effort the improved course had on their progress. A team of a recent graduate, an industry representative and another academic professional have been formed to receive direct feekback and evaluation of the project.

\section{Conclusion}

This paper describes the plans for building a new structure to the 'Electric Machines and Power' course (EET3500) in WSU-DET EET program. The objectives, planning steps and the development procedures of the project are explained. The impact of this project on engineering technology education at WSU is realized through the addition of dc/ac drives, real time data acquisition, and computer-aided simulation and analysis components to the laboratory. It provides students the opportunity to work with the motor drives similar to those that exist in the industry. In addition, visualization will help students better understand electromagnetic phenomena inside dc/ac machine. Other institutions might utilize our development that will be provided on our Web page in the future.

\section{Acknowledgement}

This work has been supported in part by the National Science Foundation Course, Curriculum, and Laboratory Improvement (CCLI) grant NSF DUE 9951391. 


\section{References:}

1. L.J. Bohmann etal., 'A Multimedia Introductory Course in Electric Energy', NSF/EPRI workshop on innovations in Power Engineering Education, Oct 30 - Nov 1, 1997.

2. L.J. Bohmann etal., 'Redefining the Introductory Electrical Energy Conversion Course', ASEE Annual Conference Proceedings, 1997.

3. H.L. Hess, 'Incorporating Electronic Motor Drives into the existing Undergraduate Electric Energy Conversion Curriculum', ASEE Annual Conference Proceedings, 1996.

4. G.G. Karady and D. Tylavsky, 'Use of Animation for Improvement of Student Understanding of Energy Conversion', ASEE Annual Conference Proceedings, 1999.

5. S. Chickamenahalli and V. Nallaperumal, V. Washeed, 'LabView Based Electric Machine Laboratory', ASEE Annual Conference Proceedings, 1998.

6. S. Chickamenahalli, C. Yeh, V. Nallaperumal, B. Madhavi, 'CBI Based Courseware Development - Lessons Learned', ASEE Annual Conference Proceedings, 1998.

7. S. Chickamenahalli and V. Nallaperumal, V. Washeed, 'Lathe Instrumentation', ASEE Annual Conference Proceedings, 1999.

8. S. Chickamenahalli, C. Yeh, V. Nallaperumal, B. Madhavi, 'Effective Visualization for an Electric Machines and Power System Course', ASEE Annual Conference Proceedings, 1999.

\section{Chih-Ping Yeh}

Chih-Ping P Yeh received the B.S. degree in Electronic Engineering from Taiwan, the M.S. degree in Biomedical Engineering from Northwestern University at Evanston, IL, the M.S. and Ph.D. degrees in Electrical Engineering from Texas A\&M University at College Station, TX. Dr. Yeh is an Associate Professor in the Division of Engineering Technology at Wayne State University, Detroit, Michigan.

\section{Mulchand S. Rathod}

Mulchand S. Rathod earned his B.E. (Mechanical) degree from Sardar Patel University in 1970; and M.S. in 1972, Ph.D. in 1975, both in Mechanical Engineering from Mississippi State University. He joined WSU as Professor and Director of the Division of Engineering Technology in 1987. His prior appointments include State University of New York at Binghamton, Tuskegee University, Jet Propulsion Laboratory, and IBM. 